\title{
The Loose Cannon! - Cutaneous Manifestation of Langerhans Cell Histiocytosis
}

\section{Bazlin Ramly}

Department of Paediatrics, University Hospital Waterford, Co Waterford, Ireland

*Corresponding author: Ramly B, Department of Paediatrics, University Hospital Waterford, Co Waterford, Ireland, Tel: +353838399421; E-mail: mrcpch2016@gmail.com

Rec Date: August 16, 2018, Acc Date: August 27, 2018, Pub Date: August 30, 2018

Copyright: (C) 2018 Ramly B. This is an open-access article distributed under the terms of the Creative Commons Attribution License, which permits unrestricted use, distribution, and reproduction in any medium, provided the original author and source are credited.

\begin{abstract}
A 6-year-old girl presented with symptoms of diabetes insipidus with no neurological abnormalities. Presence of erythematous, dried, plaque like lesions on her scalp had guided the clinicians/paediatricians to liase with different sub-specialities which included dermatologists, pathologists, haematologists, endocrinologists, oncologists, and radiologists. The diagnosis of Langerhans cell histiocytosis $(\mathrm{LCH})$ was rendered and confirmed by positive immunostaining for anti CD1a and anti S-100 protein antibodies. Other work up were done for the patient to detect any organs involved and either LCH infiltrates the liver, lungs, spleen or hematopoietic system. The patient was then treated with chemotherapy as according to LCH-IV protocol group 1 initial treatment for multisystem Langerhans Cell Histiocytosis. She responded very well to the therapy and is still under follow up. In this case, we will also be discussing about the importance of genetics of Langerhans Cell Histiocytosis.
\end{abstract}

Keywords: Langerhans; Eczema; Psoriasis; Diabetes insipidus; Chemotherapy; Immunostaining; BRAF

\section{Introduction}

Langerhans Cell Histiocytosis (LCH) which previously was known as Histiocytosis $\mathrm{X}$ is best regarded as a proliferative process that may have some malignant characteristics. The cutaneous manifestations maybe hard to be distinguished from eczema or sebarrhoeic dermatitis resulting in rather late diagnosis of $\mathrm{LCH}$. Most recent discovery showed approximately $60 \%$ of LCH biopsy specimens demonstrates the V600E mutation in the BRAF oncogene, regardless of stage or organ involvement [1]. Treatments are depending on whether they are single system or multi systems disease. It is vital that the patients are being followed up for long-term due to the possible permanent consequences such as diabetes insipidus (DI). LCH may infiltrate the pituitary stalk especially in children with craniofacial bony involvement leading to irreversible diabetes insipidus (DI).

\section{Case Report}

A 6-years-old girl presented with 3 months history of polyuria polydipsia, nocturia and some weight lost. She had been on treatment for scalp and vulva psoriasis after she was diagnosed by a paediatric dermatology team. Other than that, she was born at term with no antenatal or postnatal issues. Her vaccinations were up to date and there was no concern about her developmental milestone. On systemic examination the only positive finding was rash on the scalp (Figure 1). Bilateral erythematous/plaque like lesions were also found at the labia minora. Neurological examination was essentially normal. She was then admitted in the ward for investigation and observation. Fluid charting to record input and output was done during the admission which was documented as high as $3 \mathrm{~L} / \mathrm{m}^{2} / 24$ hours.

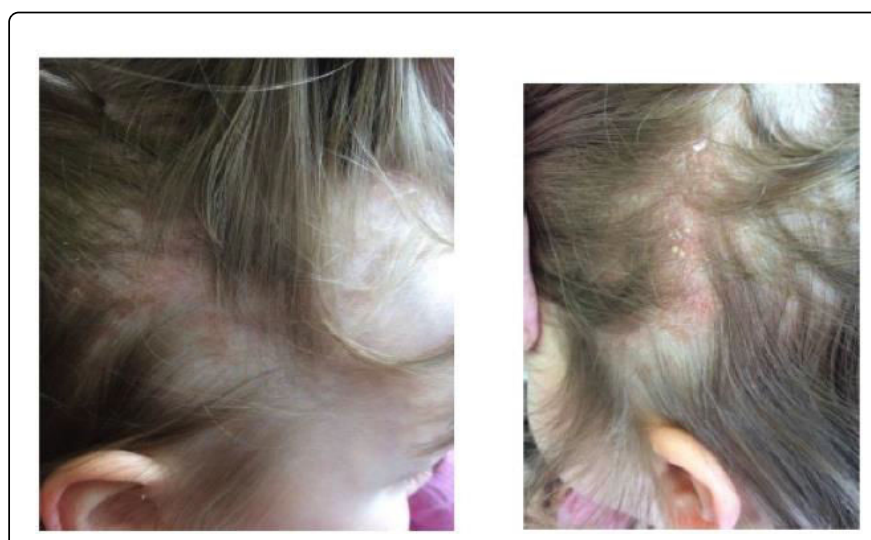

Figure 1: Erythematous macular papular plaque like lesions on the scalp at the left fronto-parietal region which was itchy. More lesions seen on the left side as compared to the right side of the scalp.

Initial blood investigations were done which included bone profile, full blood count (FBC), peripheral blood film (PBF), thyroid function test (TFT), blood glucose and HbA1C which were all normal. Electrolytes on renal function before and after water deprivation test and low level of anti-diuretic hormone $(\mathrm{ADH})$ were suggestive of central diabetes insipidus (Table 1). Ultrasound of the kidneys was normal. We proceeded on performing magnetic resonance imaging (MRI) which showed enlargement of pituitary stalk.

Since the rash on the scalp has never regressed fully, skin biopsy from the scalp area was done and it was positive for anti-CD1a and anti-S100 immunostains. 


\begin{tabular}{|c|c|c|c|}
\hline \multicolumn{4}{|c|}{ Investigations } \\
\hline \multicolumn{2}{|c|}{$1^{\text {st }}$ set of investigations } & \multicolumn{2}{|c|}{ Investigations done after fluid deprived for $3-4$ hours } \\
\hline Sodium & $139 \mathrm{mmol} / \mathrm{L}$ & Sodium & $145 \mathrm{mmol} / \mathrm{L}$ \\
\hline Potassium & $3.9 \mathrm{mmol} / \mathrm{L}$ & Potassium & $4.1 \mathrm{mmol} / \mathrm{L}$ \\
\hline $\mathrm{Cl}$ & $102 \mathrm{mmol} / \mathrm{L}$ & $\mathrm{Cl}$ & $107 \mathrm{mmol} / \mathrm{L}$ \\
\hline Urea & $3.3 \mathrm{mmol} / \mathrm{L}$ & Urea & $4.7 \mathrm{mmol} / \mathrm{L}$ \\
\hline \multicolumn{2}{|c|}{ Urine Osmol: $58 \mathrm{mOsm} / \mathrm{kg}$} & \multicolumn{2}{|c|}{ Urine Osmol: $74 \mathrm{mOsm} / \mathrm{kg}$} \\
\hline \multicolumn{2}{|c|}{ Serum Osmol: $281 \mathrm{mOsm} / \mathrm{kg}$} & \multicolumn{2}{|c|}{ Serum Osmol: 298 mOsm $/ \mathrm{kg}$} \\
\hline
\end{tabular}

Table 1: Results of the investigations done before and after water deprivation test. It was carried out as the serum osmolarity was less than 300 $\mathrm{mOsm} / \mathrm{m}^{2} / \mathrm{kg}$ but more than $270 \mathrm{mOsm} / \mathrm{m}^{2} / \mathrm{kg}$. It was done in 4 hours and needed to be halted as the patient was still urinating 6-7 times despite not having any fluid and it is shown in this table that the urine osmolarity is still significantly low.

Hence then, the child was diagnosed as Langerhans Cell Histiocytosis. Further evaluation was done whereby computed tomography scan (CT) of the head then showed infiltrations of the bones at the left side of the head but skeletal survey did not show any other bony involvement and bone marrow showed no involvement of hematopoietic system. Patient was commenced on LCH-IV Protocol Group 1 Initial Treatment for multisystem Langerhans Cell Histiocytosis and desmopressin for DI. Patient was stratified in multi-system LCH as there were involvement of skin, bone and the pituitary stalk. The $\mathrm{p}$ atient $\mathrm{r}$ esponded $\mathrm{w}$ ell $\mathrm{t}$ o $t$ he therapy and is still receiving ongoing treatment with regular follow-up. There were no genetic studies being discussed so far.

\section{Discussion}

Langerhans Cell Histiocytosis (LCH) is very rare with the incidence of 1 in 20,000 populations. The presentations can vary, and the oncogenic transformation of the cells can infiltrate any organs in the body. LCH can be divided into multi-system or single system disease and further stratified into low risk or high risk when there is involvement of haematopoietic organs such as the liver or the marrow. Approximately $50 \%$ of patients experience skin involvement at some stage of the disease. It may be the only manifestation of LCH and often misdiagnosed as eczema, allergic dermatitis or cradle cap. It is usually a hard-to-treat scaly, papular, sebarrhoeic dermatitis of the scalp, diaper, axillary, or posterior auricular regions and some may spread to the back, palms and soles [2].

As observed in our patient in this case report, $\mathrm{LCH}$ also affects the endocrine system, primarily the hypothalamic-pituitary axis (HPA), by causing deficiencies in the activity of posterior and/or anterior pituitary hormones [3] and the most common endocrine disorder associated with LCH is diabetes insipidus (DI). It can occur before, concurrently with, or many years after other multisystem manifestations of the disease that lead to the diagnosis of histiocytosis [4]. DI is established when the total of input/ output exceeds $2 \mathrm{~L} / \mathrm{m}^{2} / 24$ hours and serum osmolarity is $>300 \mathrm{mOsm} / \mathrm{m}^{2} / \mathrm{kg}$ with urine osmolarity of $<300 \mathrm{mOsm} / \mathrm{m}^{2} / \mathrm{kg}$, water deprivation test is carried out when serum osmolarity is $<300 \mathrm{mOsm} / \mathrm{m}^{2} / \mathrm{kg}$ but $>270 \mathrm{mOsm} / \mathrm{m}^{2}$ / $\mathrm{kg}$ [5] as shown in our case. DI can either be central or nephrogenic but specific to this case report, our focus is the central DI. Central DI can result from multiple other aetiologies such as infiltrative, autoimmune, neoplasms, trauma, congenital malformations of the hypothalamus or pituitary and infection though $10 \%$ of these children have idiopathic central DI [5].

Involvement of the pituitary organ in LCH may be observed as enlarged pituitary stalk which is more than $3 \mathrm{~mm}$ in size on MRI [6]. Other findings are loss of the posterior pituitary bright spot on T1weighted sequences, change in the size of the pituitary stalk and change in the height of the adenohypophysis [7]. In this specific case, the skin biopsy had actually helped the clinician to obtain the final diagnosis of $\mathrm{LCH}$ as the diagnosis of $\mathrm{LCH}$ is confirmed by the presence of Birbeck granules using electron microscopy or by positive immunohistochemical staining for the protein markers S100 and CD1a [8] as MRI findings as mentioned may similarly be found in dysgerminoma [7].

Immuno-histo-pathology has been used as a diagnostic tool for centuries but the discovery of BRAF-V600 gene has made everyone cognisant about the importance of genetics of LCH especially with regards to treatment. BRAF has an important function in the signaling cascade, which usually begins with activation of receptor tyrosine kinase and proceeds by phosphorylation steps through Ras to Raf to mitogen-activated protein kinase (such as MAP2K1, MAPKK 1 or MEK) and the extracellular signal-regulated kinase (ERK), which ultimately leads to modulation of gene expression [9]. BRAF-V600E gene mutation is found in $57 \%$ of archived LCH lesions [10]. Current treatment of $\mathrm{LCH}$ depends on the extent and severity of disease at diagnosis. Treatment is following the LCH -IV protocol which is divided into 7 groups and our patient in this case was following group 1 protocol. The finding of the BRAF-V600 gene and MAP2K1 mutations in $\mathrm{LCH}$ patients has raised the possibility of targeted therapies in histiocytic disorders and few cases were reported to have good responses though some are having side effects from the treatment [11]. Having said that, the study of genetics in Langerhans cell histiocytosis is a way of moving forward to discover better treatment and management of our patients.

\section{Conclusion}

There are many new discoveries that may improve our management in children with Langerhans Cell Histiocytosis which no doubt includes the genetic studies of it. The understanding of the disease gives clarity to the diagnostic process even with cutaneous 
Citation: Ramly B (2018) The Loose Cannon! - Cutaneous Manifestation of Langerhans Cell Histiocytosis. J Clin Case Rep 8: 1160. doi: $10.4172 / 2165-7920.10001160$

Page 3 of 3

manifestation of LCH. As DI can occur before, concurrently with, or many years after other multisystem manifestations of the disease, we would encourage children having idiopathic DI or children who are diagnosed having $\mathrm{LCH}$ should have regular imaging to detect any changes on the pituitary stalk so that treatment can be carried out sooner.

\section{References}

1. Badalian-Very G, Vergilio JA, Fleming M (2013) Pathogenesis of Langerhans cell histiocytosis. Annu Rev Pathol 8: 1-20.

2. Leonidas JC, Guelfguat M, Valderrama E (2003) Langerhans cell Histiocytosis. Lancet 361: 1293-1295.

3. Makras P, Alexandraki KI, Chrousos GP, Grossman AB, Kaltsas GA (2007) Endocrine manifestations in Langerhans cell histiocytosis. Trends Endocrinol. Metab 18: 252-257.

4. Dunger DB, Broadbent V, Yeoman E, Sekl JR, Lightman SL, et al. (1989) The frequency and natural history of diabetes insipidus in children with Langerhanscell histiocytosis. N Engl J Med 321: 1157-1162.

5. Kara A (2008) Postpartum antiretroviral prophylaxis with zidovudine, lamivudine, and nevirapine during intrapartum HIV infection. HIV Medicine 9: 452-502.
6. Leger J, Velasquez A, Garel C, Hassan M, Czernichow P (1999) Thickened pituitary stalk on magnetic resonance imaging in children with central diabetes insipidus. J Clin Endocrinol Metab 84: 1954-1960.

7. Marchand I, Barkaoui MA, Garel C, Polak M, Donadieu J (2011) For the writing committee; Central diabetes insipidus as the inaugural manifestation of Langerhans cell histiocytosis: Natural history and medical evaluation of 26 children and adolescents. J Clin Endocrinol Metab 96: 1352-1360.

8. Badalian-Very G, Vergillio JA, Fleming M, Rollins BJ (2013) Pathogenesis of langerhans cell histiocytosis. Annu Rev Pathol 24: 1-20.

9. Montagut C, Settleman J (2009) Targeting the RAF-MEK-ERK pathway in cancer therapy. Cancer Lett 283: 125-134.

10. Badalian-Very G, Vergilio JA, Degar BA (2010) Recurrent BRAF mutations in Langerhans cell histiocytosis. Blood 116: 1919-1923.

11. Abla O, Weitzman S (2015) Treatment of Langerhans cell histiocytosis: role of BRAF/MAPK inhibition. Ame Society Haematol pp: 565-570. 